\title{
Does the PPAR- $\gamma$-activating property of telmisartan provide a benefit in clinical practice?
}

\author{
Hypertension Research (2013) 36, 183; doi:10.1038/hr.2012.189; published online 29 November 2012
}

Angiotensin II type 1 (AT1) receptor blockers (ARBs) and angiotensin-converting enzyme (ACE) inhibitors are used for the treatment of hypertension and related cardiovascular diseases. As a class effect, ARBs and ACE inhibitors are well known to delay the progression to overt diabetes in hypertensive patients. In addition to its AT1 receptor-blocking action, telmisartan (TEL) has a potent peroxisome proliferator-activated receptor- $\gamma$ (PPAR- $\gamma$ )activating property. ${ }^{1}$ In the July edition of Hypertension Research Amono et al. reported for the first time, using crystallographic analysis, that TEL directly binds to the ligand-binding domain of PPAR- $\gamma .^{2}$ Based on these data, it is anticipated that TEL provides a greater beneficial effect on glucose metabolism than other ARBs and ACE inhibitors do in hypertensive patients.

To address the hypothesis, many smallscale, clinical studies have been performed, but diverse findings have been obtained. Vitale et $a .^{3}$ demonstrated in hypertensive patients with metabolic syndrome that $80 \mathrm{mg}$ per day TEL, but not $50 \mathrm{mg}$ per day losartan, for 3 months improved fasting glucose, insulin and homeostasis model assessment (HOMA) indices. ${ }^{3}$ Nagel et al. ${ }^{4}$ reported similar findings in nondiabetic, insulinresistant patients that $40 \mathrm{mg}$ per day TEL for 12 weeks caused a reduction in HOMA indices. ${ }^{4}$ On the other hand, Bahadir et al. ${ }^{5}$ showed that $80 \mathrm{mg}$ per day TEL or $50 \mathrm{mg}$ per day losartan for 8 weeks did not improve HOMA indices in hypertensive patients with metabolic syandrome. ${ }^{5}$ Bahr et al. ${ }^{6}$ also reported that 80 and $160 \mathrm{mg}$ per day TEL for 14 weeks did not exert an additional improvement in glucose metabolism in hypertensive patients. ${ }^{6}$ Finally, one largescale clinical trial in patients with high risk for vascular events showed that the incidence of diabetes in the group taking $80 \mathrm{mg}$ per day TEL for a maximum of 5 years was not significantly different from that of the group taking the ACE inhibitor ramipril at a dose of $10 \mathrm{mg}$ per day. ${ }^{7}$

Pharmacologic profiles of TEL are welldocumented. The $50 \%$ effective concentration for PPAR- $\gamma$ activation is $1-10 \mu \mathrm{mol}$, the $50 \%$ inhibitory concentration for AT1 receptor inhibition is $0.88 \mathrm{nmol},{ }^{1,8}$ and the proteinbinding rate is $99.0-99.4 \% .^{9}$ In general, protein-unbound drug is involved in the expression of pharmacological effect. As the maximal blood concentration is reported to be $280 \mathrm{ng} \mathrm{ml}^{-1}$ after oral dosing of $80 \mathrm{mg}$ TEL in hypertensive patients, ${ }^{10}$ the maximal unbound protein fraction is estimated to be 3.3-5.4 nmol, which seems to be enough to inhibit the AT1 receptor, but too low to activate PPAR- $\gamma$. Therefore, we think that although TEL activates PPAR- $\gamma$, its effect is too small to exert an additional benefit on glucose metabolism in clinical practice. The number of hypertensive patients with diabetes is rapidly increasing. Therefore, development of new ARBs with more potent PPAR- $\gamma$-activating properties is needed to further improve the outcome of these patients.

\section{CONFLICT OF INTEREST}

The authors declare no conflict of interest.

\section{Akio Fujimura, Kentarou Ushijima and Hitoshi Ando}

Department of Pharmacology, Division of Clinical Pharmacology, Jichi Medical University, Tochigi, Japan E-mail:akiofuji@jichi.ac.jp
1 Benson SC, Pershadsingh $\mathrm{HA}, \mathrm{Ho} \mathrm{Cl}$, Chittiboyina A, Desai P, Pravenec M, Qi N, Wang J, Avery MA, Kurtz TW. Identification of telmisartan as a unique angiotensin II receptor antagonist with selective PPARgammamodulating activity. Hypertension 2004; 43: 993-1002.

2 Amano Y, Yamaguchi T, Ohno K, Niimi T, Orita M, Sakashita H, Takeuchi M. Structural basis for telmisartan-mediated partial activation of PPAR gamma. Hypertens Res 2012; 35: 715-719.

3 Vitale C, Mercuro G, Castiglioni C, Cornoldi A, Tulli A, Fini M, Volterrani M, Rosano GMC. Metabolic effect of telmisartan and losartan in hypertensive patients with metabolic syandrome. Cardiovasc Diabetol 2005; 4: 6 .

4 Nagel JM, Tietz AB, Goke B, Parhofer KG. The effect of telmisartan on glucose and lipid metabolism in nondiabetic, insulin-resistant subjects. Metabolism 2006; 55: 1149-1154.

5 Bahadir O, Uzunlulu M, Oguz A, Bahadir MA. Effects of telmisartan and losartan on insulin resistance in hypertensive patients with metabolic syndrome. Hypertens Res 2007; 30: 49-53.

6 Bahr I-N, Tretter P, Kruger J, Stark RG, Schimkus J, Unger T, Kappert K, Scholze J, Parhofer KG, Kintscher $U$. High-dose treatment with telmisartan induces monocytic peroxisome proliferator-activated receptor- $\gamma$ target genes in patients with the metabolic syndrome. Hypertension 2011; 58: 725-732.

7 Yusuf S, Teo KK, Pogue J, Dyal L, Coplad I, Schumacher H, Dagenais P, Sleight P, Anderson C. Telmisartan, ramipril, or both in patients at high risk for vascular events. N Engl J Med 2008; 358: 1547-1549.

8 Koike H, Konse T, Sada T, Ikeda T, Hyogo A, Hinman D, Saito H, Yanagisawa H. Olmesartan medoxomil, a novel potent angiotensin II blocker. Ann Rep Sankyo Res Lab 2003; 55: 1-91.

9 European Medicines Agency European public assessment report (MicardisPlus) http://www.ema.europa. eu/docs/en_GB/document_library/EPAR_-_Scientific_Discussion/human/000413/WC500028547.pdflast update: 6 May 2009.

10 Israili ZH. Clinical pharmacokinetics of angiotensin II (AT1) receptor blockers in hypertension. J Hum Hypertens 2000; 14: S73-S86. 